\title{
Emotion Regulation on Wives Victims of Domestic Violence in Christianity Undergoing the Forgiveness Phases
}

\section{Petra Johanna, Irmawati, Josetta Maria Remila Tuapattinaja}

\author{
Department of Clinical Psychology \\ University of Sumatera Utara \\ Email: johannapetra@yahoo.com
}

\begin{abstract}
Christian family wives. The principle of Christian marriage is no divorce except by death. This study aims to examine the dynamics of emotional regulation on the wives of victims of violence in Christian households in undergoing forgiveness phases with a qualitative approach and three participants. There are five emotional regulation strategies: situation selection, situation modification, attentional deployment, cognitive change and response modulation. There are four forgiveness phases: uncovering, decision, works and deepening. The results showed that all three participants underwent the four phases of forgiveness in the same direction, as well as experiencing repetition in the work and deepening phases. In undergoing each phase of forgiveness, they used the five or part of the emotional regulation strategy in the same direction or back and forth. The most of the emotional regulation strategy used to achieve forgiveness are cognitive change by reappraisal their suffering through studying God's words of forgiveness and response modulation by still loved their husband and mother-in-law and prayed for them, also become good wife and mother.
\end{abstract}

Keywords-emotional regulation; forgiveness; role of belief

\section{INTRODUCTION}

Christian marriage is designated as a home of love and a place of fostering a godly family that glorifies the name of God in their lives (Bible, Genesis 1: 26-31; Ephesians 5:22-33). In Christian marriage, the union of men and women as husband and wife is bound by a biblical promise, to be uttered by the bridegroom and the bride. This promise of marriage is a pledge of eternal fellowship uttered earnestly before God, pastor and in front of the congregation who attended the wedding. This promise of marriage contains the statement that the husband and wife agree to each other faithfully, love each other and appreciate a lifetime both in joy and sorrow, rich and poor, and in good health or illness, to maintain the unity, harmony, and happiness of the household.

The World Health Organization (2017) stated that one in three (35\%) women in the world experience physical and sexual abuse throughout their lives by their partners. Of the cases of domestic violence only $30 \%$ of victims who reported the case. In general, $38 \%$ of women who experienced domestic violence died killed by their partners. The Asian Pacific Institute on Gender-Based Violence (2017) stated that 41$61 \%$ of women in Asia report experiencing physical and sexual abuse throughout their lives from their partners.
In Indonesia, according to Komnas Perempuan (2017), the number of cases of domestic violence for the year of 2014 amounted to 293,220 cases. The amount is obtained from various sources of Religious Courts as many as 280,710 cases, and Non-Governmental Organizations (NGOs) as many as 12,510 cases. Cases handled by NGOs show that nearly $50 \%$ of victims of domestic violence are Christian wives or women who are threatened by divorce. By 2015 the number of cases of domestic violence has increased to 321,752 cases, sourced from the Religious Courts of 305,535 cases, and from NGOs of 16,217 cases. The cases handled by these NGOs continue to show that nearly $50 \%$ of victims of domestic violence are Christian wives or women who are threatened by divorce. Meanwhile, according to NGOs Psd in Medan, who specifically handled domestic violence said that every month they handle cases 5-10 cases and sometimes even more than that. Of the number of cases they handled, about $40-50 \%$ of victims are Christian wives who are threatened divorce. Then according to the Counseling Department of an X church in Medan city, almost every month of the year, a wife comes for counseling about her domestic violence problem and considers divorce.

When husband and wife experienced life problems such as domestic violence then the household is faced two things namely divorce or 
keep the integrity of the household. Forgiveness is essential to maintaining the unity of Christian households. Enright (Enright \& North, 1998) said forgiveness is the process of replacing those negative emotions with positive emotions of compassion, empathy to the perpetrator, even the affection of the perpetrator and self so that the victim becomes forgive to itself and the perpetrator. Forgiveness has four phases: 1) the uncovering phase is the phase of expressing negative emotions without shame; 2) decision phase, decides to forgiveness; 3) work phase, start process apply forgiveness; 4) deepening phase, the phase of getting results from the application of forgiveness, eg. a relief because regardless of unforgive conditions, get new meaning \& hope in his life.

According to Enright (Enright \& North, 1998) for an individual can undergo the fourth phase of forgiveness, the individual must be able to perform emotional regulation. This is confirmed by Gross (2014) that relationships with spouses who commit violence can be salvaged depending on the individual's emotional regulatory capacity and the desire to maintain their household unity. If the individual or spouse wants the relationship to persist and return harmoniously, then the offended individual must regulate his/her emotions in order to direct him/her to forgiveness towards his/her partner.

Gross (2014) stated that emotion regulation is a conscious or unconscious strategy to maintain, strengthen or reduce one or more emotional and behavioral responses. There are five emotion regulation strategies that are 1) situation selection, individuals approaching, avoiding situations that can cause excessive emotion or plan activities to reduce excessive emotion; 2) situation modification, the individual changes the environment so that it will contribute to reducing the strong influence of emerging emotions; 3) attentional deployment, the individual shifts the focus of attention (distraction) to different aspects of the situation, distracts (changing internal focus) from one situation to another (different situations), and diverts the focus of attention from situations of violence by remembering things fun; 4) cognitive change, the individual gets a chance to change his way of thinking, appraisal the situation and changes his emotional response, the individual reappraisal the situation or problem it faces by changing the way of thinking so as to reduce or adding strong influence to positive or negative emotions; and 5) response modulation, the individual tries to expressive suppression, as well as the individual tries to prevent a continuous negative or positive emotion-expressive behavior by breathing, exercising, relaxation, expressing positive emotions and behaviors.

This study wants to know the dynamics of emotion regulation on the wife of victims of Christian domestic violence in undergoing forgiveness phases.

\section{A. Method}

\section{METHODS}

This research used the qualitative method with in-depth interview technique on the three study participants.

\section{B. Participants}

Participants in this study were three wives of victims of violence in Christian households who had been forgiveness. The first participant was 75 years old and experienced domestic violence about 47 years. The second participant was 37 years old and experienced domestic violence about 12 years. The third participant was 41 years old and experienced domestic violence about 11 years.

\section{RESULTS AND DISCUSSION}

According to Enright (Enright \& North, 1998) to achieve forgiveness, the individual who in this case is the wife of the victim of domestic violence must undergo four phases: uncovering phase, decision phase, work phase and deepening phase. These phases can be lived in the same direction, back and forth or jumping up to the deepening phase. If the individual has reached the deepening phase, then the individual has forgiveness. The results of this study found that all three participants underwent four forgiveness phases in the same direction, ranging from the uncovering phase, decision phase, the work phase, to the deepening phase and emotional relief, and have begun to provide forgiveness. It is just that the three participants were experiencing repetition in undergoing the phase of work and deepening phase. This happens because living of status of the three participants who still interacted and even lived with the perpetrators of violence (the first and the second participants lived with their husband and mother-in-law, and the third participant lived with her husband). The three participants were still experiencing physical, economic and psychological violence, also there is no deep meaning that forgiveness has not been fully achieved. 
Enright (Enright \& North, 1998) and Gross (2014) stated the success of these phases is determined by the ability of individual emotional regulation. This is found in all three participants, using the same or different regulation in each phase. Gross (2014) stated emotion regulation can be done using the fifth or a part of the strategy. In this study, it was found that emotion regulation in uncovering phase in the first and third participant used the five emotional regulatory strategies, whereas the second participant only used four strategies: situation selection, situation modification, cognitive change and response modulation. The first participant and the third participant used the five strategies in the uncovering phase, with the condition that they were still living with their husbands. Meanwhile, the second participant used the five strategies at work phase with status still living with husband and mother-in-law.

The second participant moved faster from the uncovering phase to the decision phase until the deepening phase. The speed of migration of the second participant from the uncovering phase to the decision phase rather than the first and third participant because of by reappraisal in the cognitive change that the four emotion regulation strategies used in the uncovering phase (situation selection, situation modification, cognitive change and response modulation) was ineffective in overcoming heartache, anger and bitterness at the attitude and treatment of her mother-in-law and husband. She also realized emotion regulation of crying and regretting the fate of every day cannot provide a solution to the problem. Therefore the second participant decided to accept her suffering and condition of life by reappraisal in cognitive change.

According to Kubler-Ross in Sarafino (2006) who said that a person can survive in his misery and become psychologically healthy if he or she has been able to accept his or her condition. The person no longer solved his or her problem with emotion-focused coping but has moved on to problem-focused coping. That was what the second participant experienced. She forgave to her husband so that she felt relief, not easily hurt or bitterness and always forgiveness to her husband and accepted sincerely her husband who was a womanizer. She used cognitive change (reappraisal) and response modulation in this transition phase.

Effect of the second participant still lived with mother-in-law and her husband in the decision phase, the second participant was still experiencing psychic and physical violence directly and continuously. As a result, the second participant undergoing the work phase was about six to seven years. While the first participant underwent a work phase for about eighteen years but without psychological and physical violence directly because she has separated from her husband. Meanwhile, the third participant underwent in a work phase of one to two years without direct violent psychological and physical violence because of separation from her husband.

At this time, the second participants have used different emotion regulation of cognitive change (reappraisal) and response modulation for decision and deepening phases. This was in line with Gross's (2014) statement that the factors affecting the emotion regulatory strategy were the frequencies of the use of such emotion regulatory strategies. If the use of emotion regulatory strategies was perceived to be effective, then individuals still used the emotion regulatory strategy. But if the use of emotion regulation was not effective, then individuals moved on to other emotion regulatory strategies.

This also happened to the first participant and third participant. They changed the used of the five emotion regulatory strategies in the uncovering phase to cognitive change (reappraisal) and response modulation for decision and deepening phases. This was consistent with Gross's (2014) theory that individuals whose habits often used their cognitive abilities to overcome their problems and perceive the effectiveness and benefits of their cognitive abilities had a habit of using cognitive change and response modulation in dealing with their problems. The individual used his/her cognitive ability to re-analyze (reappraisal) the problem until he/her found the solution and meaning of the problem.

Emotion regulation using cognitive change in the uncovering phase was only an appraisal to the violent situation faced by the three participants at the time. But when it has entered the decision to deepening phase, all three participants had a meaning change that the strategy used so far was not effective in managing negative emotions and reaching the solution of the problem. They did reappraisal in line with the increasing understanding of God's word obtained during worship, while undergoing counseling with counselors in the church, and the willingness to learn the word of God and more intensely in prayer.

According to Robert (2002) women who experienced continuous violence for more than 
two years or between 2-35 years may result in chronic psychological severity and suicide or killing. The results of this study found that the three participants did not experience such things. They defended their domestic life because it holds the principle of Christian doctrine that says there is no divorce other than death. This was in line with the results of researched Moe and Popkees (2012) which stated that forgiveness was very important for the psychological health of Christian women. They can also forgiveness because of their beliefs about God until now. This was in line with the results of Zawawi's research (2015) which stated commitment to religion in forgiveness will produce a good psychological on victims of violence. Gross (2014) also said one of the factors that affect the emotional regulation of individuals to be able to manage negative emotions to be positive is their beliefs. Therefore it can be concluded that forgiveness is very effective for the wife of victims of domestic violence in line with the results of Theodora (2008), Salama (2012), Jenkins (2012) and Enright, Pork, Essex, Waxler and Klatt (2013) researches. Then it can be concluded also that emotional regulation was effective to undergo forgiveness phase in line with Kurniati's research (2009), Malone, Meyer, Tarlton, Waslelewski, Reuben, West \& Mitchell (2011), and Baker (2014).

According to Robert (2002) for the psychological comfort of victims of domestic violence so that they can rose from the suffering it took social support to the victim. This was found in this study, all three participants can forgiveness and rose from their misery for social support. At first the first participant did not get social support both from the husband's side and her party but finally got support from church counselor and friends of the church so that participants finally dared to choose to separate from husband without divorce. The second participant received social support from church counselor and her family so that she dared to decide to move and separate from husband without divorce. The third participant received social support from family and church counselor. This was in line with the results of Enright's (2011) studied that the victims of domestic violence can recover and rise from the problem if they forgiveness and the better it becomes if they gained support from their social environment.

Hooberman (2010) stated that for the sake of better mental health and victim life, victims of violence were not only forgiveness but also forgot what they have experienced and move forward without being affected by the existence of the perpetrators for their good. It is found in this study that all three participants remained forgiveness to their husbands and continue their life by choosing to separate from their husbands without divorce for their psychological comfort and their children because the behavior of domestic violence is still done by their husband. This was also in line with Robert (2002) for the safety of victims of violence, the cycle of violence must be stopped first.

\section{Forgiveness}

\section{CONCLUSION AND FINDINGS}

All three participants have been forgiveness by undergoing uncovering, decision, work and deepening phases through the dynamics of their respective emotion regulation. While undergoing a deepening phase, all three participants experienced a repetition of the work phase. This happens because the married life status of the three participants who still interacted or lived with the perpetrators of violence (the first and second participants lived with their husband and mother-in-law, the third participant lived with her husband) so that experiencing physical and psychological or economic violent. In addition, there was no deep meaning of forgiveness at first entering the deepening phase. However, after several years of work phase, the participants returned to reach deepening phase and really had forgiveness.

2. Uncovering phase

To release their negative emotions in the uncovering phase, the first and third participant using the five emotion regulatory strategies of situation selection, situation modification, attentional deployment, cognitive change and response modulation. While the second participant used four emotion of regulation strategy that is situation selection, situation modification, cognitive change and response modulation. The first and third participant underwent this uncovering phase for a long time. The first participant took more than twenty years, while the third participant required about nine years. Meanwhile, the second participant was relatively fast in this uncovering phase is about five years. Speed moved from the uncovering phase to the decision phase because second participant by reappraisal her suffering and begin deciding forgiveness by releasing her negative emotions.

3. Decision phase

The emotion of regulation strategies used in deciding for forgiveness in the decision phase 
by all participants is a cognitive change and response modulation. Cognitive change strategy in decision phase was different from cognitive change strategy in uncovering phase. In the uncovering phase the only appraisal to the situation of violence faced by the three participants at that time in releasing negative emotions that have not found a solution to their suffering. When entering the decision phase until the deepening phase, the three of participants used reappraisal about their suffering and had experienced a change of meaning that the strategy used so far was not effective in managing negative emotions and found solutions to the problem of forgiveness. This reappraisal ability is gained by the three participants in line with the increasing in the understanding of God's word gained during the service while counseling with counselors in the church, and studying the Words of God and praying individually and intensely.

4. Work phase

The three participants in applying forgiveness to the work phase were different. The first participant used cognitive change and response modulation. The second participant used the five emotional regulatory strategies that were situation selection, situation modification, attentional deployment, cognitive change and response modulation. While the third participant using situation selection and response modulation. This difference was due to the condition of marriage and interaction with domestic violence perpetrators. The first participant marriage conditions choose to separate from her husband and still interacted with her husband and mother-in-law (as perpetrators of domestic violence) so that still experiencing economic and psychological violence not directly. The first participant underwent a working phase of over twenty years. While the second participant was still lived with mother-in-laws and husband (as the perpetrator of domestic violence) about five years so still experiencing physical, psychological and economic violence directly. Then she separated from her mother-in-law, living with her husband and children about a year so she was still directly experienced psychological and economic violence. Finally, she separated from her husband without divorce until now. Meanwhile, the third participant was abandoned by her husband (as the perpetrator of domestic violence) without divorce. But still interacted and experienced economic and psychological violence. She underwent a working phase of more than one year.

\section{Deepening phase}

As a decisive phase of achievement of forgiveness, all three participants used cognitive change and response modulation strategies to live it. In this deepening phase, the first participant found the meaning that her suffering might her realized that her purpose in life was not money, but to love, to know God and to serve the Lord; bitterness was a toxic to herself and might her improper to worship God so that first participant apply forgiveness by loving her husband and mother-in-law and praying for them, fostering interactions, helping them in their distress until they died, and teaching their children to continue to love and honor their father and their father's family. The second participant found that her suffering might her more acquainted with God and God's help by keeping away from bitterness or remaining forgiveness, still loving her husband and motherin-law and praying for them, teaching their son to love and honor his father. The third participant found that her suffering was only because of misunderstanding, interpreting her suffering as a way of the third participant getting to know and surrender to God, still love her husband and pray for him, keep interacting with her husband and teach her children to keep loving and respecting their father.

6. Cognitive change and response modulation as keys to achieving forgiveness

An important emotion of regulation strategy for achieving forgiveness was cognitive change by reappraisal about its suffering through the deepening of the Words of God about forgiveness, followed by a response modulation that still loves the perpetrators of domestic violence, praying for husbands and or mother-inlaws (as perpetrators of domestic violence), teaching children to love and honor their father and their father's family.

7. The role of belief

The role of belief to God might the three participants could survive in the face of suffering since in the uncovering phase so as to move forward to the deepening phase to maintain the integrity of the household and achieve forgiveness.

8. The role of social support

The existence of social support from fellow believers in the church environment might the participants did not feel alone in the face of violence experienced and abled to make the decision to stay in the household in accordance with the provisions in the Christian family principle. 


\section{ACKNOWLEDGEMENT}

Thanks to Professor Dr. Irmawati and Josetta Maria Remila Tuapattinaja, M.Si, who has guided me so that I can finish this research to the end.

\section{BIBLIOGRAPHY}

Adam, G., dan Markus, H.R. (2004). Toward a conception of culture suitable for a social psychology of culture. In $M$. Schaller dan C.S. Crandall (Eds.). Psychological foundation of culture (pp. 335-360). Mahwah, N.J.: Erlbaum.

Alea, N., Black, S., dan Semegon, A.B. (2004). Young and older adults'expression of emotional experience: Do autobiographical narratives tell a different story? Journal of adult development, 11, 235-250.

Alkitab. (2009). Jakarta: Lembaga Alkitab Indonesia.

Al-Mabuk, R. H., Dedrick, C. V. L., and Vanderah, K. M. 1998. Attributing Retraining in Forgiveness Therapy. Journal of Family Psychotherapy, 9, 11-30.

Amini, F., Doodman, P., Edalati, A., Abbasi, Z., Redzuan, M. (2014). A Study on the Relationship between Religiosity and Forgiveness among Students. Applied

Science Reports www.pscipub.com/ASREISSN: 2310-9440 / P- ISSN: 2311-0139 DOI: $\quad 10,15192$ PSCP.ASR.2014.1.3.131134.

Fakultas

Ekonomi dan Ilmu Sosial, Payame

Noor University, PO Box. 19395-3697, Tehran, Iran.

Asean Pacific Institute on gender-based violence. (2017). http://www.apigbv.org/resources/violence-against-apiwomen.php. Diunduh 23 Januari 2017.

Baker, J.C. (2014). Emotion regulation and the implication for forgiveness: An investigation of the late positve potential. Desertasi. The faculty of Rosemead School of Psychology Biola University.
Butt, M.M., Sanam, F.. Gulzar, S., \& Yahya, F. (2013). Cognitive emotional regulation and forgiveness. GC University, Lahore, Pakistan. Interdisciplinary Journal of Contemporary Research and Forgiveness. DOI: 10,15192 PSCP.ASR.2014.1.3.131134 .

Baumeister, R. F., Exline, J. J., and Sommer, K. L. (1998). The victim role, grudge theory, and two dimensions of forgiveness. In E. L. Worthington, Jr. (eds.), Dimensions of forgiveness: Psychological research and theological speculations. Philadelphia: The Templeton Foundation Press.

Brooks, C.W. (2007). Forgiveness and Empathy in Victims of Sexual Aggression and Their Relationship with Mental and Physical Health. Dissertation. UMI Microform 3298345 Copyright 2008 by ProQuest Information and Learning Company. Idaho State University.

Cassano, M.C., dan Zeman, J.L. (2010). Parental socialization of sadness regulation in middle childhood: The role of expectations and gender. Developmental Psychology, 46, 1214-1226.

Carstensen, L.L., and Mikels, J.A. (2005). At the intersection of emotion and cognition: Aging and positivity effect. Current direction in psychological science, 14 , 117-121.

Charles, S.T. (2005). Viewing injustice: Age differences in emotional experience. Psychology and aging, 20, 159-164.

Corey \& Corey. (2006). I never knew I had a choice: Explanations for personal growth. 8th ed. New York: Thomson Brooks/Cole.

Deering, S.S. (2011). Forgiveness and empathy in the victim of domestic violence and their relationship with spirituality. Dissertation. Pacifica Graduate Institute. UMI 3500701 Copyright 2012 by ProQuest LLC.

D'Adrade, R.G., (1984). Culture meaning system. In R.A.Shweder dan R.A., Levine (Eds.). Culture theory: Essays on mind, self, and emotion (pp. 88- 199). Cambridge, UK: Cambridge University Press. 
Enright, R. D. \& North, J. (eds.) (1998). Exploring forgiveness. Madison, Wisconsin: University of Wisconsin Press.

Enright, R.D., \& Magnuson, C.H. (2008). The church as a forgiving community: An initial model. Journal of Psychology \& Theologia. Madison: $\quad$ University of Wisconsin.

Enright, R.D., Pork, J.H., Essex, M.J., Waxler, C.Z., \& Klatt, J.S. (2013). Forgiveness intervention for female South Korean adolescent aggression victim. Madison: University of Wisconsin.

Enright, R.D. (2011). Psychological Science of Forgiveness: Implication for Psychotherapy and Education. Madison: University of Wisconsin.

Gull, M., and Rana, S.A. (2013). Manifestation of Forgiveness, Subjective Well- Being and Quality of Life. Journal of Behavioural Sciences, Vol. 23, No. 2. Government College University, Lahore, Pakistan.

Gross, J.J. (2014). Handbook of Emotion Regulation. Second Edition. New York: The Guilford Press.

Hooberman, R. (2010). Forgiving, forgetting, and moving on. United Kingdom: Jason Aronson.

Hukumonline. (2016). Undang-undang Penghapusan Kekerasan Dalam Rumah Tangga. Sumber: www. hukumoline. com. Diunduh 04 Sepetember 2016.

Jenkins, T. (2012). Forgiveness as a healing agent in cases of traumatic violence. British

Columbia: School of Criminology Simon Fraser University Burnaby.

Keeling. J., \& Mason, T. (2008). Domestic violence. A multi-professional approach for healthcare practitioners. Chester, UK. McGrawhill: Open University Press.

Komnas Perempuan. (2017). http://www.komnasperempuan.go.id/lem bar-fakta- catatan- tahunancatahu-2016-7-maret-2016/, diunduh 23 Januari 2017.
Kumala, A,. dan Trihandayani, D. (2015). Peran Memaafkan dan Sabar dalam Menciptakan Kepuasan Perkawinan. Jurnal Ilmiah Penelitian Psikologi: Kajian Empiris \& Non-Empiris. Vol. 1, No. 1, 2015. Hal. 39-44. Universitas Muhammadiyah Prof. DR. Hamka.

Kurniati, N.M.T. (2009). Memaafkan Kaitannya dengan Empati dan Pengelolaan Emosi. Universitas Gunadarma. Proceeding PESAT (Psikologi, Ekonomin, Sastra, Arsitektur \& Teknik Sipil) Universitas Gunadarma-Depok 20-21 Oktober 2009. Diunduh 20 Sepetember 2016.

Malone, A., Meyer, D.D., Tarlton, T., Waslelewski, L., Reuben P., West C., \& Mitchell, V. (2011).The Relationship Between Forgiveness and Emotional WellBeing. Reagent University http://counselingoutfitters.com/vistas/vi stas11/Article_23.pdf. Dunduh 21 Maret 2016.

Macaskill, A., Maltby, J., and Liza D. (2002). Forgiveness of Self and Others and Emotional Empathy, The Journal of Social Psychology, 142 (5), 663-665.

McCullough, M.E, Wortington, E.L, and Rachal, K.C. (1997). Interpersonal Forgiving in Close Relationships. Journal of Personality and Social Psychology 73 (2), $321-336$.

McCullough, M.E, Wortington, E.L, Rachal, K.C, Sandage, S.J., Brown, S.W, and Hight, T.L. (1998). Interpersonal Forgiving in Close Relationships : II. Theoritical 11 Elaboration and Measurement. Journal of Personality and Social Psychology, 75, (6), 1586-1603.

Mc.Cullough, M.E., Pargement, K.I., \& Thoresen, C.E. (2001). Forgiveness. Theory,

Research, and Practice. New Tork: The Guilford Press.

McCullough, M.E, Fincham, F.D and Tsang, J. 2003. Forgiveness, Forbearance and Time: The Temporal Unfolding of Transgression-Related Interpersonal Motivations. Journal of Personality and Social Psychology, 84 (3), 540557. 
Mirzadeh, M., and Fallahchai, R. (2012). The relationship between Forgiveness and Marital Satisfaction. Journal of Life Science and Biomedicine, J.Life Sci.Biomed.2(6): 278-282, 2012. Department of Psychology, Hormozgan University, P.o.Box 3995Bandar Abbas-Iran.

Moe, G.Q., and Popkees, S. (2012). Forgiveness and Health in Christian Women. $J$ Relig Health (2014) 53:204-216 DOI 10.1007/s10943-012-9603-g. Missouri Western State University.

Nakkita. (2015).

http://nakkitanakkami.blogspot.co.id/201

5/07/janji-pernikahan- danimplikasinya.html, diakses 23 Januari 2017.

Nancy, M.N. (2013). Hubungan Nilai dalam Perkawinan dan Pemaafan dengan

Keharmonisan Keluarga. Proceeding PESAT (Psikologi, Ekonomi, Sastra, Arsitektur \& Teknik Sipil) Vol. 5 Oktober 2013 Bandung, 8-9 Oktober 2013. Universitas Katolik Soegijapranata.

Patton, M.Q. (1991: 2009). Metode Evaluasi Kualitatif. Yogyakarta: Pustaka Belajar.

Poerwandari, E.K. (2000). Kekerasan terhadap perempuan: Tinjauan psikologi feministik. Dalam Luhulima, A.S. (Ed). Pemahaman bentuk-bentuk tindak kekerasan terhadap perempuan dan alternatif pemecahannya. (Hal 11- 50). Jakarta: Penerbit PT Alumni.

Poerwandari, E.K. (2009). Pendekatan kualitatif dalam penelitian psikologi. Jakarta: Pendidikan Psikologi (PSP3) UI.

Poerwandari,E.K.(2000).http://esterlianawati.wo rdpress.com/2011/06/25/dampakpsikis- kekerasan-dalam-rumah-tangga/ diakes pada 23 Januari 2017.

Robert, A.R. (2002). Handbook of domestic violence intervention strategies. New York: Oxford University.

Rothhart, M.K., Ziaie, H., \& O’Boyle, C.G. (1992). Self-regulation and emotion in infancy. In N.Eisenberg \& R.A. Fabes (Eds.). Emotion and its regulation in early development (pp.7-23). San Fransisco: Jossey-Bass.
Sadiq, R., and Ali, A.Z. (2012). Forgiveness, and Its Relationship With Well- Being Among Married Women In Joint Family. Pakistan Journal of Clinical Psychology, 2012, II I.59-68. Institute of Clinical Psychology, University of Karachi.

Salama, N. (2012). Memaafkan sebagai upaya psikoterapi (Manfaat dan proses memaafkan menurut perspektif korban). Semarang: IAIN Bandung.

Samson, A., \& Gross, J.J. (2012). Humor as emotion regulation: The differential consequences of negative versus positif humor. Cognition and Emotion, 26, 375384. Diunduh 20 September 2016.

Sarafino, E.P. (2006). Health Psychology: Biopsychosocial Interactions. $5^{\text {th }}$. New York: John Wiley \& Sons, Inc

Saraswati, R. (2009). Perempuan dan Penyelesaian Kekerasan Dalam Rumah Tangga. Bandung: PT.Citra Aditya Bakti.

Sari, K. (2012). Forgiveness pada Istri sebagai Upaya untuk Mengembalikan Keutuhan

Rumah Tangga akibat Perselingkuhan Suami. Jurnal Psikologi Undip Vol. 11, No.1, April 2012. Universitas Syiah Kuala Banda Aceh.

Smedes, L.B. (1984). Forgive and Forget: Healing The Hurts We Don't Deserve. San Francisco: Harpersan.

Scimone, B. (2007). A Qualitative Study Investigating Self-Concept in Female Survivors of Domestic Violence with Substance Abuse Problems. Clinical Dissertation. Presented to the Faculty of the California School of Professional Psychology at Alliant International University San Diego.

Takaku, S. (2001). The Affects of Apology and Perspective Taking on Interpersonal Forgiveness: A Dissonance-Attribution Model of Interpersonal Forgiveness.Journal of Social Psychology, 141 (4), 494-508. 
Theodora, J. (2008). Tahapan Forgiveness Pada Istri Korban Kekerasan Dalam Rumah Tangga. USU: repository.com. Diunduh 17 Maret 2016.

Thiruchselvam, R., Hajcak, G., \& Gross, J.J. (2012). Looking inwards: Shifting attention within working memory representations alters emotional responses. Psychological Science, 23(12), 1461-1466.

Thompson, R.A. (1990). Emotion and selfregulation. Socioemotional development: Nebraska Symposium on motivation (Vol.36, pp.367-467). Lincoln: University of Nebraska Press.

Thompson, L.Y., Synder, C.R., Hoffman, L., Michael, S.T. et al. (2005). Dispositional Forgiveness of Self, Others, and Situation. Journal of Personality. 73:2, April 2005 @Blackwell Publishing 2005 DOI: 10.1111/j.1467-6494.2005.00311.x. Diunduh 20 September 2016.

Toussaint, L.L., Worthington, E.L., \& Williams, D.R. (2015). Forgiveness and Health. New York: Springer Science+Business Media.

Tutu, D. (2014). The Book of Forgiving. New York: Harper Collin.

Ulus, L. (2015). Empathy and Forgiveness Relationship. International Journal of Research in Humanities and Social Studies Volume 2, Issue 8, August 2015, PP 98-103. Child Development Department, Etlik Vocational High School, Ankara, Turkey.

World Health Organization. (2017). http://www.who.int/mediacentre/factshee ts/fs239/en/. Accessed on 23 January 2017.

Worthington, E.L. (2005). The Handbook of forgiveness. New York: Taylor \& Francis Group, LLC

Worthington, E.L. (2006). Forgiveness and reconciliation. Theory and Application. New York: Taylor \& Francis Group, LLC

Worthington, E.L., and Scherer, M. (2004). Forgiveness is an emotional focused coping strategy that can reduce health risks and promote health. Resilience: Theory,
Review, and Hypotheses. Psychology and Health. Vol 19 (3). 385-405. Accessed on 21 March 2016.

Yalcın, I., and Malkoc, A. (2014). The Relationship Between Meaning In life and Subjective Well-Being, Forgiveness, and Hope as mediator. J Happiness Stud (2015) 16: 915-929 DOI 10,1007 / s10902-014-9540-5. Divisi Bimbingan dan Konseling Psikologis, Universitas Trakya Edirne, Turki.

Zawawi, J.A. (2015). Religious Commitment and Psychological Well-Being: Forgiveness as a mediator. Jurnal Ilmiah Europa Ledisi February 2015 vol.11, No.5 ISSN: 1857-7881 (Print) e - ISSN 1857-7431 117. Educational Psychology Department, Hashemite University, Zarqa- Jordan.

Zechmeister, J.S., and Romero, C. (2002). Victim and Offender Accounts of Interpersonal Conflict: Autobiographical Narratives of Forgiveness and Unforgiveness. Journal of Personality and Social Psychology, 82 (4), 675- 686. 